\title{
Measuring Industrial Customer Satisfaction: The Case of the Natural Gas Market in Greece
}

\author{
Dimitrios Drosos ${ }^{1}$, Michalis Skordoulis ${ }^{2, * \mathbb{C}}$, Garyfallos Arabatzis ${ }^{2}$, Nikos Tsotsolas ${ }^{1}$ \\ and Spyros Galatsidas ${ }^{2}$ (I) \\ 1 Department of Business Administration, School of Business, Economics and Social Sciences, \\ University of West Attica, 12244 Egaleo, Greece; drososd@uniwa.gr (D.D.); ntsotsol@uniwa.gr (N.T.) \\ 2 Department of Forestry and Management of the Environment and Natural Resources, \\ School of Agricultural and Forestry Sciences, Democritus University of Thrace, 68200 Orestiada, Greece; \\ garamp@fmenr.duth.gr (G.A.); sgalatsi@fmenr.duth.gr (S.G.) \\ * Correspondence: mskordoulis@gmail.com
}

Received: 29 January 2019; Accepted: 25 March 2019; Published: 30 March 2019

check for updates

\begin{abstract}
This aim of this paper is to measure industrial consumer satisfaction in the natural gas sector in Greece. By using the Multicriteria Satisfaction Analysis (MUSA) method, the paper measures industrial customer satisfaction based on criteria concerning the provided products and services, communication and collaboration with providers' staff, customer service, pricing policy and website. The research results that are based on the analysis of 95 questionnaires collected during the period between June 2017 and October 2017 show that the index of the global customer has a good performance as its value is about $74.99 \%$. Furthermore, the satisfaction criterion with the highest performance is the one concerning communication and collaboration with natural gas providers' staff. It should be noted that the criterion concerning the provided products and services criterion is the only one with high performance and importance-meaning that it should be in the spotlight of the natural gas providers. The paper concludes that there is considerable space for improvements to be made. Customer satisfaction is of great importance for every company, as it can be highly connected with its performance. Using the results of this study, natural gas providers will have the chance to frame their future actions in order to keep their industrial customers satisfied. Taking into account both the fact that industrial customers' share in the Greek natural gas market is about $25 \%$ and that this market has been recently liberalized, it is of vital importance for natural gas providers to have sufficient information about their industrial customers' satisfaction.
\end{abstract}

Keywords: natural gas; energy market; customer satisfaction; industrial customers; multicriteria analysis

\section{Introduction}

It is widely known to both the companies and the consumers, that customer satisfaction, is one of the most significant factors that can guarantee success [1]. Day by day, consumers become increasingly more demanding for the quality of products and services they receive. They demand that the product or the service they pay for, fulfills their needs, is of high quality and is also offered at an affordable price.

Furthermore, it is a fact that every company, regardless of the field in which it operates, must find ways to keep its customers and attract new ones, while at the same time being competitive and profitable. As customers have access to more information nowadays, they become more flexible in their decisions and have more choices than ever before, it is even more important for companies to earn their trust. Furthermore, today's consumers have an educational level that allows them to judge any product or service they pay for, while they demand the best possible products and services at the 
same time. Consequently, a company that meets or even exceeds their customers' expectations has a significant competitive advantage [2].

Despite the fact that customer satisfaction is in the spotlight of many years of research, most literature focuses on the satisfaction concerning retail consumers instead of the industrial ones [3]. In recent years, most academic research on customer satisfaction has focused on consumer goods and services. Current studies concerning consumer goods and services typically relate satisfaction to a single discrete transaction [4-6]. On the other hand, studies concerning industrial customer satisfaction have emphasized the importance of customer-supplier relationships [7-9]. It is obvious that customer satisfaction in the industrial sector is understood as a relationship-specific rather than a transaction-specific construct $[3,10]$.

Energy is one of the key regulators of the interaction between nature and humans. Many environmental issues that lead to negative consequences for society, the economy and the sustainability of the environment are connected with the production, transformation, and use of energy [11]. The efficient treatment of these issues is a vital necessity [12]. Therefore, the need for ecologically friendly and cleaner forms of energy is becoming more and more imperative [13,14]. As a result of the big changes in the global energy system coming from the above needs-which will take place in the following decades, renewable sources of energy are expected to be the grand victors in the race for the increasing energy demand supply [15-17]. Despite the fact that natural gas is not a renewable source of energy, it is relatively cleaner than its alternatives [18].

Thus, during the last decades, the demand for both renewable and cleaner sources of energy has increased considerably both on the retail and industrial customer level. The quality of the services provided by the clean energy supply companies and the satisfaction of their customers, have been particularly important for them during the last few years. Therefore, for the energy supply companies, the measurement of their customers' satisfaction is a contemporary tool for strategic planning, capable of creating the necessary conditions for their survival and development.

The main objective of the present research is to measure industrial customer satisfaction of natural gas providers in Greece using a multicriteria analysis method. The methodological approach is based on the principles of multicriteria modelling as the Multicriteria Satisfaction Analysis (MUSA) Method is used for the satisfaction measurement.

\section{Literature Review}

\subsection{Industrial Customers' Satisfaction}

Several studies show that the long-term success of an organization is closely related to its ability to adapt to its customer needs and changing preferences [19-22]. The analysis of customer satisfaction and its comparison with the results of similar studies can provide policy makers with a unique insight into the motivations and satisfaction of consumers [23-25].

Furthermore, customers have access to an educational level that allows them to judge any product or service they pay for, while they demand the best possible products and services at the lowest price. Consequently, a company that meets or even exceeds a customer's expectations has a significant competitive advantage [26-28]. Therefore, it is important for every company to know who its customers are, what they expect and how adequately their expectations are met. This process is of the same importance for both the retail and industrial consumers [29].

The theory of customer satisfaction has been presented in international literature, as a reliable tool for the evaluation of a company's results. Customer satisfaction under the view of perceived quality may be seen as the difference between the actual and the expected quality of a product or a service. Many researchers emphasize on satisfaction with functional attributes [30].

According to Ostrom and Iacobucci [31], customer satisfaction is a way to evaluate the gap between the expectations of a customer from a particular product or service, and what the customer receives after the use of said product. For the measurement of customer satisfaction certain indexes, 
price, efficiency or total performance of a company are being used. Woodside et al. [32], considers customer satisfaction the main factor that affects their behavior. Yi [33], defines customer satisfaction in two basic ways: either as a result or as a procedure. Furthermore, Yi [33] considers that the definition of customer satisfaction varies, depending on a series of definitive factors that concern the satisfaction from a product or service, a buying decision experience, a performance attribute, the end-user experience, a company shop or department and, the satisfaction from a pre-buying experience.

Churchill and Suprenant [6] state that "satisfaction is the result of purchase and use of a product or service, which derives from the customer's comparison between the remuneration and the cost of purchase, taking into consideration the expected result". Customer satisfaction is also based on customer knowledge, which is about products, suppliers and markets [34].

Kotler [35], approaching the issue of customer satisfaction from a marketing point of view, has analyzed the meaning of customer satisfaction as feelings of pleasure or discontent, which can be derived from the comparison between the performance or the result of a product or service, and the expectations the person developed before paying for it.

In recent years, it has been widely recognized that customer satisfaction is an essential tool of corporate marketing strategies. According to O'Sullivan and McCallig [36], customer satisfaction has a positive impact on a firm's value. The researchers found that this impact is higher than the impact its earnings have on its value. They also found that customer satisfaction positively and significantly moderates the earnings-firm value relationship. Other researchers found that customer satisfaction has a direct and positive effect on customer purchase intentions and loyalty [37-39].

Based on the abovementioned analysis, we can conclude that high levels of customer satisfaction can lead to customer loyalty [40-42], business profitability [43,44], trust [45], customer retention [41], positive word-of-mouth [46,47], repeating sales [42,48], future revenues [49-54] increased stock prices [49,55-57], and higher market share [58,59].

During recent decades, most researchers on customer satisfaction have focused on satisfaction with consumer goods and services. As far as the satisfaction of industrial customers is concerned, research is still not particularly advanced [60].

Raj et al. [61] defines industrial customer satisfaction as a relationship-specific construct, describing how well a supplier meets a customer's expectation in the following areas: product-related information, services, complaint handling, order handling, product features, interaction with internal staff and interaction with salespeople.

Industrial customers' satisfaction is closely connected with the quality of the provided products and services provided to them, and is necessary for the continuous improvement and excellence of any company [62-64]. As is the case of retail customers, industrial customers' satisfaction is also connected with the performance of companies and the development of a competitive advantage [6]. However, industrial customer satisfaction is found to be much more complex [3].

Homburg and Rudolph [3] developed a valid customer satisfaction measure for industrial customers, the INDSAT model. The model consists of seven distinct satisfaction dimensions: products, salespeople, product-related information, order handling, technical services, interaction with internal staff, and complaint handling.

\subsection{Customer Satisfaction Surveys in Energy Sector}

Throughout the last years, several studies have been carried out concerning customer satisfaction with energy providers. Generally, satisfaction in the energy sector covers the quality of a number of services, such as the provision of a new connection, the billing, the handling of customer requests, and complaints. Customer satisfaction can be a significant motivating factor for energy providers. The main objective of an energy organization is to acquire quality products and services that satisfy its customers with measurable improvements to mission capability and operational support in at a fair and reasonable price [65]. 
Customers who are satisfied with the service quality they receive, tend to trust their energy provider. Customer satisfaction is a prominent theme in the energy sector. Satisfied customers have the potential to become loyal customers and to attract new customers to an energy provider [66,67].

Mutua et al. [68], formulated a general framework for the study of customer satisfaction in the energy sector (electricity, petroleum, biomass, and renewable energy) in Kenya, using the European Consumer Satisfaction Index (ECSI). They found that customer satisfaction is highest in the renewable energy sector at $74.71 \%$, followed by the petroleum sector at $62.32 \%$ and the biomass sector at $61.82 \%$. The electricity sector has the least satisfied customers at $53.06 \%$.

J.D. Power and Associates [69] conducted a study to measure business customer satisfaction with gas utility companies in four U.S.A geographic regions (East, Midwest, South, and West). This research is based on responses from 10,635 U.S. companies that spend about $\$ 150$ per month on natural gas. The study examines six satisfaction criteria; corporate citizenship, billing and payment, communications, price, customer service and field service. The overall satisfaction among business customers of gas utilities averages at 674 on a 1000-point scale.

Moreover, J.D. Power and Associates [70] using the same set of criteria, measures residential customers' satisfaction with their gas utility in the same geographic regions in the U.S.A. Retail gas customers were reportedly more satisfied (overall satisfaction 706 index points on a 1000-point scale), than the industrial ones.

Ipsos, London Economics, and Deloitte [71] conducted consumer market research on the functioning of retail energy markets in the European Union (EU). The research covers all European Union Member States, Norway, and Iceland. Across the European Union countries, $40 \%$ of survey respondents "strongly agreed" (scores 8 to 10) that their energy provider offered an overall high quality of service, $40 \%$ "agreed" (scores 5 to 7 ) and finally 15\% "disagreed" (scores 0 to 4 ). In Greece, 30\% of survey respondents "strongly agreed", $41 \%$ "agreed" while $26 \%$ "disagreed".

The American Customer Satisfaction Index (ACSI) analyzed customer satisfaction with investor-owned energy utilities serving U.S. residential customers (electric and natural gas service). According the ACSI Customer Satisfaction Reports [71] the natural gas remains the superlative energy source with an improved score of 78\% (100-point scale). The Residential household satisfaction with electricity is lower at $75 \%$.

Liu et al. [72], developed an evaluation index system of electric power customers' satisfaction based on the service blueprint theory. The service blueprint model is divided into 4 parts, which are customer behavior, front office staff behavior, back office staff behavior, and support process.

Chodzaza and Gombachika [73], focused on functional quality offered by the public electricity provider to its industrial customers within Southern Region of Malawi. The findings suggest that the service quality is poor, irrespective of demographic characteristics of the industrial customers. The industrial customers were dissatisfied with the availability of power and customer care services.

Jannadi and Al-Saggaf [74], conducted a study to measure the customer satisfaction of a typical energy provider in Saudi Arabia. The study revealed that the provider had high satisfaction scores in tangibles dimensions, but low ones in the dimensions of responsiveness and reliability.

Medjoudj et al. [75], analyzed the customer satisfaction of power users in Bejaia City, Algeria, using the Analytic Hierarchy Process (AHP) method. The obtained results indicate the advantage of investment to improve customer satisfaction and enterprise profitability.

Medjoudj et al. [75] used three multi-criteria decision making methods (cost benefit analysis, economic criteria inspired from game theory, and the analytic hierarchy process) to find that customer satisfaction with energy providers is expressed by the requirements of high quality of service at the lowest possible cost of electricity.

Ibáñez et al. [76] proposed a framework where retail customer satisfaction with energy providers is correlated with the dimensions of technical quality of the core services (supply interruption, and service re-establishment), technical quality of the peripheral services (information, consultation, and flexible contracts) and, service process quality (prompt service, politeness, and customer requests). Their 
results confirmed the direct impact of the examined dimensions on customer satisfaction. Following the same path, Hartman and Ibáñez [77], proposed a conceptual framework for the impact of satisfaction and switching costs on customer loyalty in energy markets. The main factors related to customer satisfaction according to their analysis are technical quality of the core services, technical quality of the peripheral services, service process quality, value added services, innovations, environmental and social commitment, and pricing policy [77]. Their results show that in order to increase customer satisfaction with energy providers and thus, indirectly, customer loyalty—service quality should be increased [77].

Price seems to be important for the industrial customers of energy providers. However, even in this case, it is shown that industrial customers' satisfaction has an important effect on price tolerance even when switching barriers exist [78]. This is supported by the finding that even in the case of high switching barriers, they are not big enough to retain dissatisfied industrial customers [78].

\subsection{Natural Gas Market in Greece}

The use of natural gas is a strategic choice for the European Union. By using natural gas, the goal is the transition to an economy based on more environmentally friendly sources of energy than oil, while also being the turning point to renewable sources of energy. The above mentioned data can support the fact that natural gas is the second most used type of energy in the European Union, while it takes the third position in world level (Figure 1).

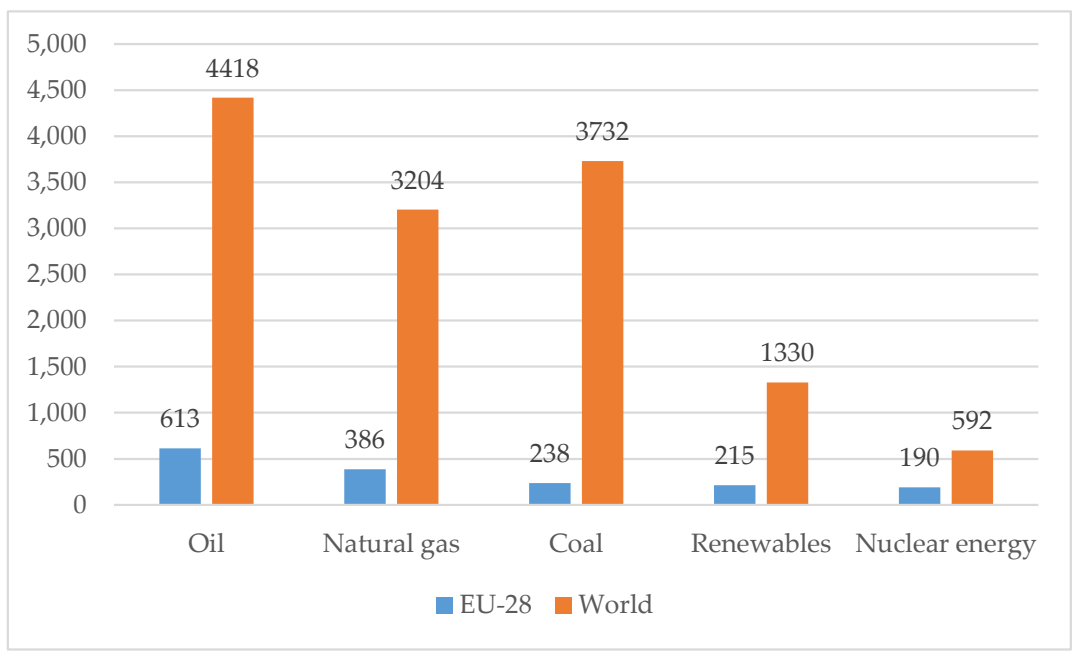

Figure 1. Worldwide energy consumption by type (in million tons of oil equivalent) [79].

As already mentioned, after oil $(42 \%)$, natural gas is the most used type of energy in the European Union (23\%). However, Greece is mostly based on oil consumption (66\%), while natural gas consumption is equal to $4 \%$ of the total energy consumption balance (Figure 2). This shows that natural gas has a low level of penetration in the Greek market, meaning that there is enough space for growth.

To clearly describe the energy market of Greece, it is notable that the sectors of electricity and natural gas have undergone radical reforms during the last decade towards the full liberalization on the basis of European energy integration. The aim is both the sustainability of the energy system and the security of supply. Another important aspect of these reforms is the creation of conditions for the competitive functioning of the market. The right to choose an electricity supplier for all consumers has been established since 2008. Full liberalization of the natural gas market has also taken place since the beginning of 2018.

Greece fully depends on natural gas imports, with the greater proportion of its supplies coming from Russia, Algeria and Turkey. More specifically, Russian natural gas is 75\% of total imports (DEPA). 
The Public Company of Gas Supply of Greece (DEPA) was found in 1988 and has been the main importer of natural gas pipes and liquefied natural gas (LNG) in Greece ever since. Total natural gas consumption in Greece, seems to follow the established trend of the European Union countries.

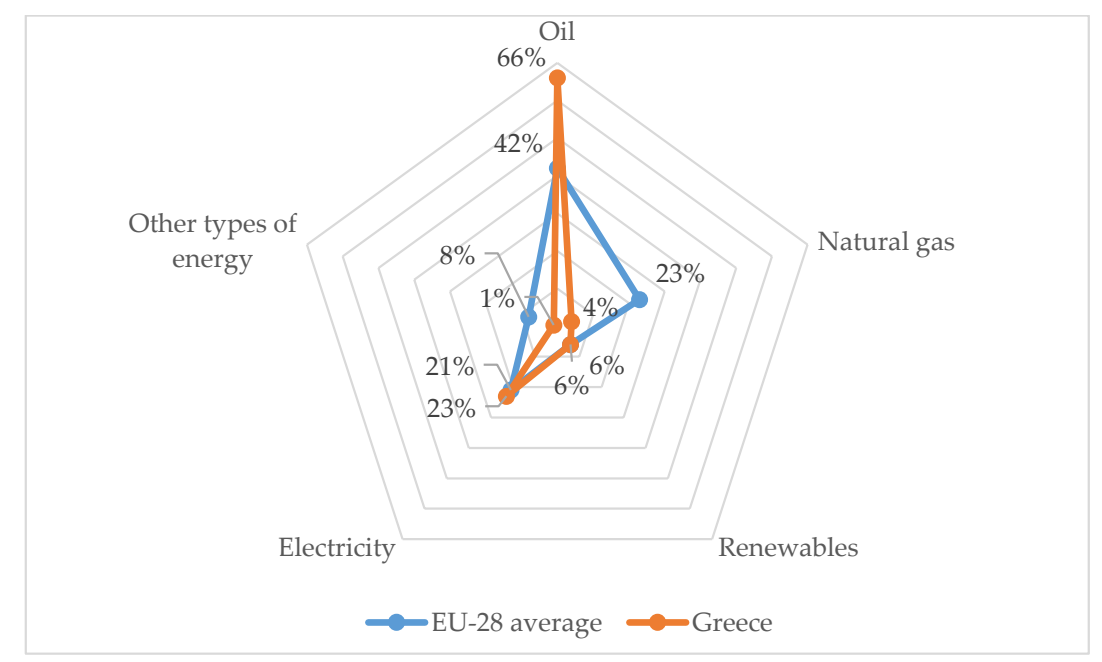

Figure 2. EU-28 average and Greece energy consumption by type (in \% percent) [80].

Furthermore, according to Eurostat, natural gas prices in Greece follow the average prices of the European Union countries (including taxes and levies) as a decline has been recorded in recent years. More specifically, natural gas prices have decreased from $€ 19.44$ in 2012 to $€ 16.41$ in 2018 per gigajoule in the European Union countries, while in Greece they have decreased from $€ 28.25$ in 2012 to $€ 14.79$ in 2018 per gigajoule [80] (Figure 3).

Based on data provided by DEPA [81], the largest part of natural gas in Greece is used for electricity production (55\%); industrial customers occupy a big percentage of the total market as their share is about $25 \%$, while $19 \%$ of natural gas consumption is for home usage and $1 \%$ for vehicles.

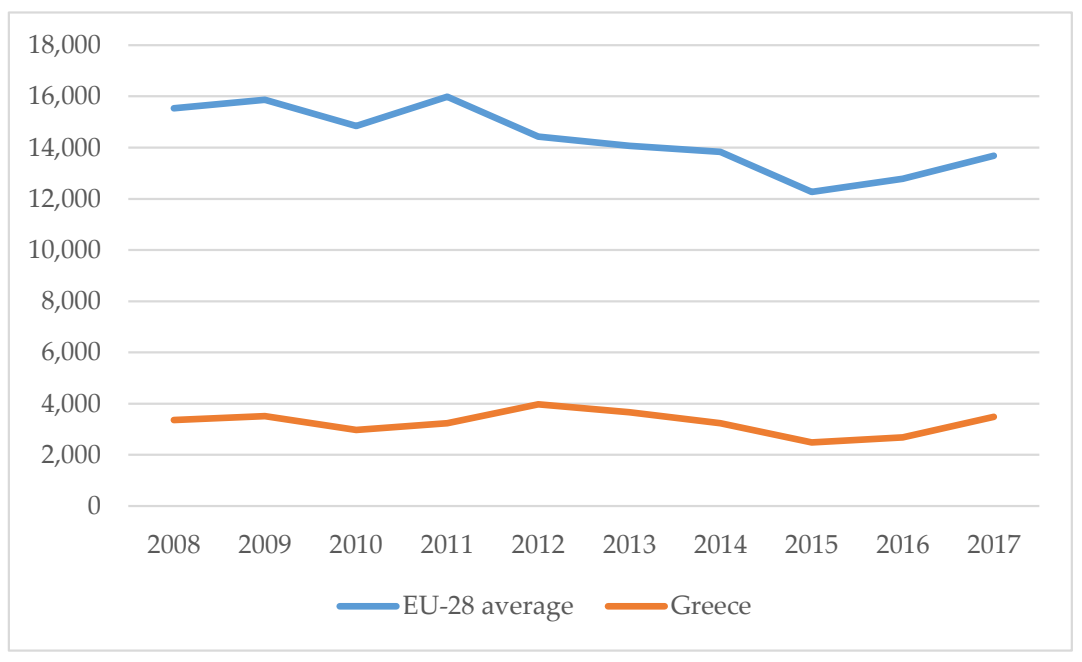

Figure 3. EU-28 average and Greece gross inland consumption of natural gas (in thousand tons of oil equivalent) [80].

\section{Research Methodology}

\subsection{Data and Research Tool}

The current study is based on a survey that took place between June and October 2017. The main research tool was a questionnaire, which was electronically distributed to 630 companies in order 
to be answered by the responsible managers for energy planning. We note that the managers who were asked occupied common positions, since according to literature $[3,60]$ different roles may have a different model of preferences. Finally, 95 questionnaires were responded resulting in an overall response rate of approximately $15 \%$. The survey focused on companies belonging to business sectors that account for about $60 \%$ of the total production of the Greek economy and use natural gas (Figure 4). The sample was randomly selected based on the data provided by published sectoral studies.

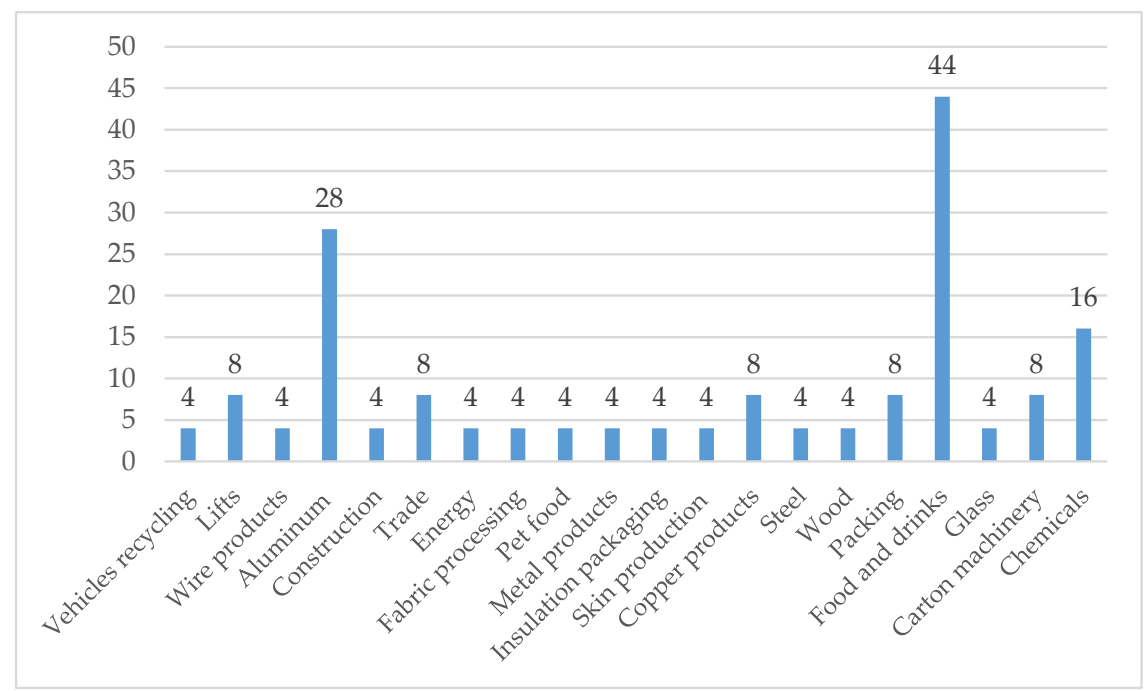

Figure 4. Number of companies took part in the survey categorized by industrial sector.

In order to design the questionnaire, the existing literature was examined. Based on the literature review and the specific characteristic of the natural gas market in Greece, a series of satisfaction criteria and sub-criteria emerged, as presented in Table 1.

Table 1. Satisfaction criteria and sub-criteria.

\begin{tabular}{|c|c|c|c|}
\hline Satisfaction Criteria & \multicolumn{3}{|c|}{ Satisfaction Sub-Criteria } \\
\hline Products-services $[3,61,65,68-70,75,77]$ & $\begin{array}{ll}\text { 1. } & \text { Range of services } \\
\text { 2. } & \text { Connection costs } \\
\text { 3. } & \text { Connection process } \\
\text { 4. } & \text { Technical problems solving }\end{array}$ & 5. & Emergency response \\
\hline $\begin{array}{l}\text { Communication and collaboration } \\
\text { with staff }[3,60,61,65,68,72,76]\end{array}$ & $\begin{array}{ll}\text { 1. } & \text { Kindness \& willingness } \\
\text { 2. } & \text { Knowledge \& skills } \\
\text { 3. } & \text { Professionalism } \\
\text { 4. } & \text { Reliability }\end{array}$ & 5. & Confidentiality \\
\hline Customer service $[3,61,69,70,72-74,76]$ & $\begin{array}{ll}\text { 1. } & \text { Promises keeping } \\
\text { 2. } & \text { Responses direct } \\
\text { 3. } & \text { Effectiveness } \\
\text { 4. } & \text { Information provision }\end{array}$ & $\begin{array}{l}5 . \\
6 .\end{array}$ & $\begin{array}{l}\text { Absence of errors } \\
\text { Accounts accuracy }\end{array}$ \\
\hline Pricing policy $[3,60,65,69,70,75,77,78]$ & $\begin{array}{ll}\text { 1. } & \text { Charges } \\
\text { 2. } & \text { Value for money } \\
\text { 3. } & \text { Payment methods } \\
\text { 4. } & \text { Prices flexibility } \\
\text { 5. } & \text { Discounts }\end{array}$ & $\begin{array}{l}6 . \\
7 .\end{array}$ & $\begin{array}{l}\text { Update changes } \\
\text { Payment terms }\end{array}$ \\
\hline Website $[61,72,76,77]$ & $\begin{array}{ll}\text { 1. } & \text { Information } \\
\text { 2. } & \text { Navigation ease } \\
\text { 3. } & \text { Loading speed } \\
\text { 4. } & \text { Aesthetic design }\end{array}$ & 5. & Content \\
\hline
\end{tabular}


A five point Likert scale was used to measure respondents' level of satisfaction rating from totally dissatisfied (1) to totally satisfied (5). Including the above mentioned satisfaction oriented questions, a total of 35 questions were answered by each of the respondents to the research.

The research data were analyzed using the Multicriteria Satisfaction Analysis (MUSA) method. The MUSA method which will be applied in the present research, uses satisfaction data collected through special questionnaires. Each respondent is asked through a questionnaire, to express satisfaction which depends on a set of criteria and sub-criteria [82].

\subsection{An Overview of the Mulitcriteria Satisfaction Analysis (MUSA) Method}

The MUSA (Multicriteria Satisfaction Analysis) method is a multicriteria preference disaggregation analysis technique $[63,83]$. The method assumes that customer's global satisfaction depends on criteria representing satisfaction dimensions; its main objective is the aggregation of judgments into a collective value function of satisfaction. The method is based on ordinal regression in order to facilitate that global satisfaction becomes as consistent as possible with customers' judgments.

More specifically, the method infers an additive collective value function $Y^{*}$ and a set of partial satisfaction functions $X_{i}^{*}$, given customer's global satisfaction $Y$ and partial satisfaction $X_{i}$. The main objective of is to achieve the maximum consistency between the value function $Y^{*}$ and the judgments of Y. The method's ordinal regression function is following one:

$$
\left\{\begin{array}{c}
\mathrm{Y}^{*}=\sum_{\mathrm{i}=1}^{\mathrm{n}} \mathrm{b}_{\mathrm{i}} \mathrm{X}_{\mathrm{i}}^{*} \\
\sum_{\mathrm{i}=1}^{\mathrm{n}} \mathrm{b}_{\mathrm{i}}=1
\end{array}\right.
$$

where $Y^{*}$ is the estimation of global satisfaction, $n$ is the number of satisfaction criteria and $b_{i}$ is a positive weight of the i-th criterion.

In order to face the problem of the model's stability, an optimality analysis stage is included. The final solution is obtained by exploring the polyhedron of near optimal solutions and is calculated by a number of linear programs equal to the number of the satisfaction criteria:

$$
\left\{\begin{array}{c}
{[\max ] \mathrm{F} /=\sum_{k=1}^{a_{i}-1} \mathrm{w}_{\mathrm{ik}} \gamma\llcorner\alpha \mathrm{i}=1,2, \ldots, \mathrm{n}} \\
\text { under the constraints : } \\
\mathrm{F} \leq \mathrm{F}^{*}+\varepsilon
\end{array}\right.
$$

where $\varepsilon$ is a small percentage of $\mathrm{F}^{*}$. The average of the solutions given by the $\mathrm{n}$ LPs may be taken as the final solution. In case of non-stability this average solution is less representative.

The assessment of a performance norm may be very useful in customer satisfaction analysis. The average global and partial satisfaction indices are used for this purpose and can be assessed according to the following equations:

$$
\mathrm{S}=\sum_{\mathrm{m}=1}^{\mathrm{a}} \mathrm{p}^{\mathrm{m}} \mathrm{y}{ }^{* \mathrm{~m}} \text { and } \mathrm{S}_{\mathrm{i}}=\sum_{\mathrm{k}=1}^{\mathrm{a}_{\mathrm{i}}} \mathrm{p}_{\mathrm{i}}^{\mathrm{k}} \mathrm{x}_{\mathrm{i}}^{* \mathrm{k}}
$$

where $S$ and $S_{i}$ are the average global and partial satisfaction indices, and $\mathrm{p}^{\mathrm{m}}$ and $\mathrm{p}_{\mathrm{i}}^{\mathrm{k}}$ are the frequencies of customers belonging to the $\mathrm{y}^{\mathrm{m}}$ and $\mathrm{x}_{\mathrm{i}}{ }^{\mathrm{k}}$ satisfaction level, respectively.

\section{Research Results}

Table 2 summarizes the reliability of the scales. The results show that all the dimensions used in the research were highly reliable based on Cronbach's a values. 
Table 2. Satisfaction criteria reliability.

\begin{tabular}{ccc}
\hline Satisfaction Criteria & Number of Sub-Criteria & Cronbach's a \\
\hline Products-services & 5 & 0.801 \\
Communication and collaboration with staff & 5 & 0.710 \\
Customer service & 6 & 0.725 \\
Pricing policy & 7 & 0.823 \\
Website & 5 & 0.703 \\
\hline
\end{tabular}

As stated above, satisfaction measurement is based on five main criteria. Approaching the importance of these criteria, shaped by the answers of industrial customers, it is shown that the criterion with the greatest importance is products and services $(24.46 \%)$, while website $(17.9 \%)$ is the one with the least importance (Table 3). These results are in accordance with the results of previous studies where products and services seem to be very important for industrial customers [76,77]. Furthermore, we may see that pricing policy seems to be of low importance $(18.10 \%)$ (Table 3$)$. This can be the result of the fact that the price of natural gas in Greece is lower than the EU-28 average.

Table 3. Satisfaction criteria weights.

\begin{tabular}{cc}
\hline Satisfaction Criteria & Level of Importance for Global Satisfaction \\
\hline Products-services & $24.50 \%$ \\
Communication and collaboration with staff & $19.60 \%$ \\
Customer service & $19.90 \%$ \\
Pricing policy & $18.10 \%$ \\
Website & $17.90 \%$ \\
\hline
\end{tabular}

The criterion with the highest level of satisfaction is this of communication and cooperation with staff with an $86.46 \%$ percentage followed by customer service and products-services criteria with $85.31 \%$ and $78.99 \%$ levels of satisfaction respectively (Table 4).

Table 4. Satisfaction criteria indexes.

\begin{tabular}{cc}
\hline Satisfaction Criteria & Level of Satisfaction \\
\hline Products-services & $78.99 \%$ \\
Communication and collaboration with staff & $86.46 \%$ \\
Customer service & $83.51 \%$ \\
Pricing policy & $55.58 \%$ \\
Website & $70.47 \%$ \\
\hline
\end{tabular}

Regarding industrial customers' level of global satisfaction, $6.82 \%$ of them were totally dissatisfied or dissatisfied, $27.27 \%$ were neutral, $40.91 \%$ were satisfied and $25 \%$ were totally satisfied (Table 5). In relation to retail customers' satisfaction as presented in the results of Ipsos, London Economics and Deloitte [84] analysis, industrial customers' satisfaction is lower. This is in line with the results of other studies where industrial customers have lower level of satisfaction than the retail ones [73].

Table 5. Industrial customers' global satisfaction.

\begin{tabular}{cc}
\hline Satisfaction Scale & Level of Satisfaction \\
\hline Totally dissatisfied & $4.55 \%$ \\
Dissatisfied & $2.27 \%$ \\
Neutral & $27.27 \%$ \\
Satisfied & $40.91 \%$ \\
Totally satisfied & $25 \%$ \\
\hline
\end{tabular}


Based on Figure 5, the results of the survey are positive, as the average global satisfaction index of the customers is about $74.99 \%$. According to the theory established by the MUSA method, the growth trend of the satisfaction function means that industrial customers are demanding about the products and services they receive $[63,83]$. These obtained results confirm the fact that industrial customers are more demanding than retail ones. Industrial customer demandingness is a critical factor for their suppliers as such customers can often get easily dissatisfied with the existing products and services so as they are searching for new to replace the old ones [85].

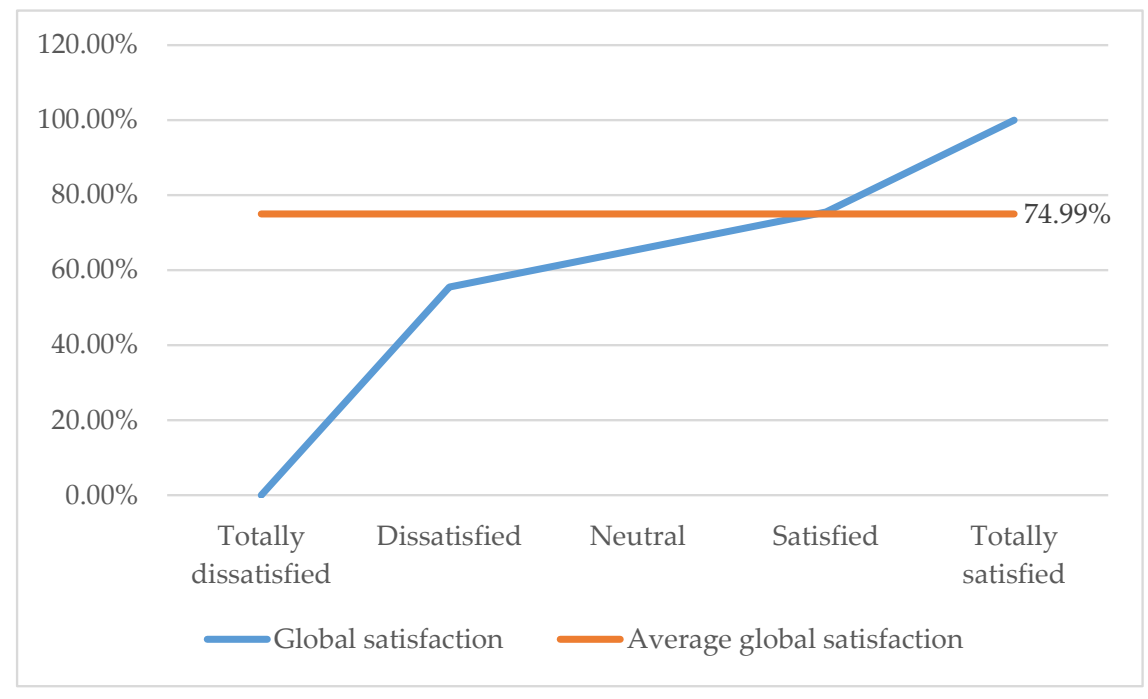

Figure 5. Global satisfaction function and average global satisfaction index.

Lastly, Figure 6 shows the strong and weak points of the natural gas providers examined. The criteria concerning pricing policy and website are located in the so-called "status quo area" of the action diagram. It should be noted that if these criteria show higher levels of significance in the future without improving the level of satisfaction, global satisfaction will get significantly worse.

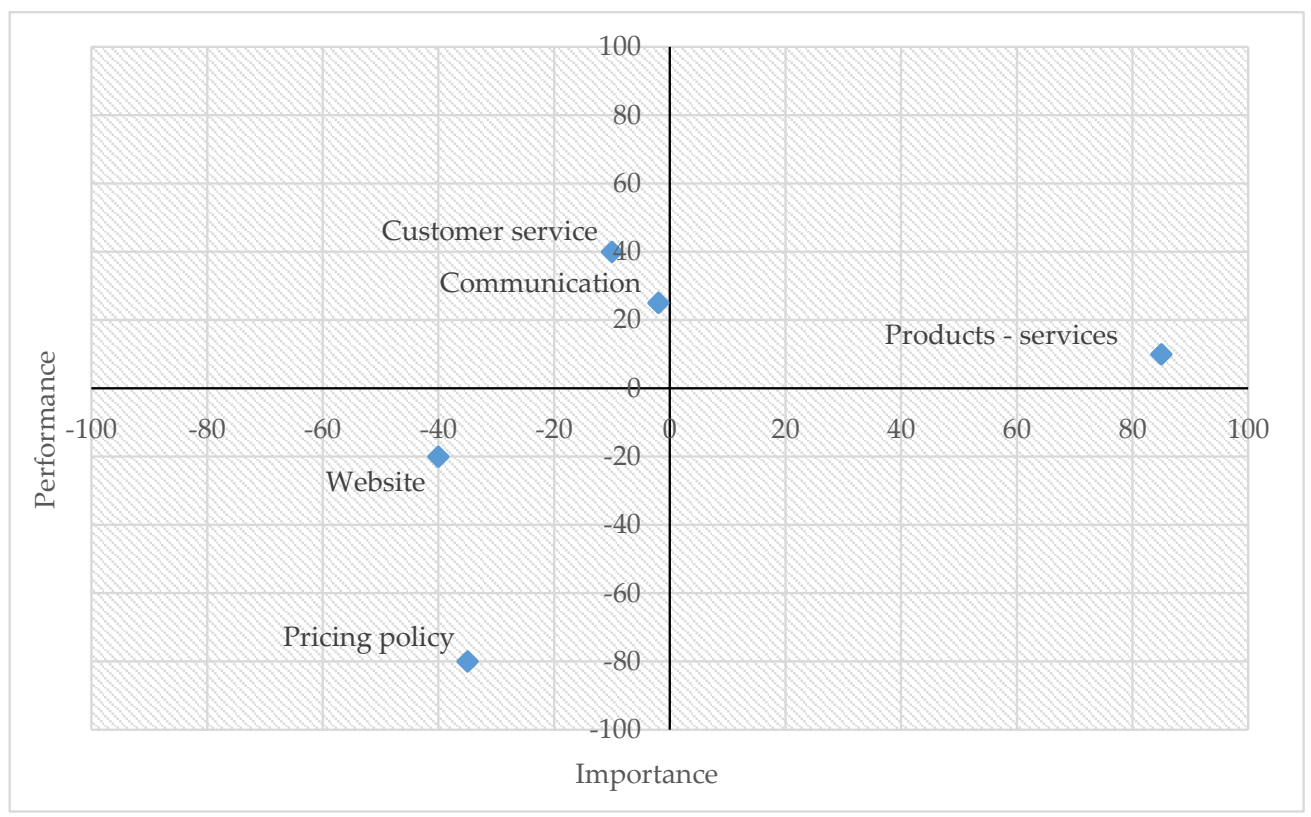

Figure 6. Satisfaction criteria action diagram.

The "products-services" criterion is located in the leverage opportunity area of the action diagram, which means that this criterion is of high performance and importance; thus, it is the criterion where 
the greatest attention should be paid. As far as it is concerned, this criterion should be in the spotlight of conservation actions and investments, as it could be characterized as a competitive edge for the market's companies.

Finally, the criteria "communication and collaboration with staff" and "customer service" are located in the transfer resources area which means that no funds should be invested for improving them, as they are of low importance.

The above mentioned results are useful in order to be used as a guidance for the examined companies' managers. However it is important to see if there is the need for a different approach to various industrial customers. In order to ascertain this assumption, a Kruskal Wallis test will be performed for using the industrial sector of the companies responded to the research as the independent variable (Table 6).

Table 6. Kruskal Wallis test's results.

\begin{tabular}{cccc}
\hline Satisfaction Criteria & Chi-Square & df & $p$-Value \\
\hline Products-services & 9.412 & 4 & 0.082 \\
Communication and collaboration with staff & 3.877 & 4 & 0.423 \\
Customer service & 2.597 & 4 & 0.627 \\
Pricing policy & 3.170 & 4 & 0.530 \\
Website & 9.017 & 4 & 0.061 \\
Global satisfaction & 4.751 & 4 & 0.314 \\
\hline
\end{tabular}

Based on Table 6 data, we see that in a $5 \%$ level of significance, there is no statistically significant difference between the levels of satisfaction and the industrial sector of the respondents. Thus, we may conclude that the above mentioned satisfaction criteria would be useful for measuring industrial customers' satisfaction belonging to the same sectors of the respondents to the research. Moreover, the strategy which must be followed by the natural gas providers based on the research results, could be the same for all the industrial customers of these sectors.

\section{Discussion and Conclusions}

The aim of this research was to measure industrial customer satisfaction with natural gas providers in Greece. Customer satisfaction can be a core determinant of the performance of any organization $[1,3,86]$. In the case of industrial customers, satisfaction can be of even greater importance due to the fact that such customers can easily seek new suppliers [85].

Research results show an adequate satisfaction level in the global satisfaction level about $74.99 \%$. This level of satisfaction can be characterized as adequate, due to the fact that industrial customers are more demanding than retail ones and at the same time may have lower levels of satisfaction than the retail ones [73,85]. However, keeping in mind the fact that the percentage of neutral customers (either satisfied or dissatisfied) is around $27 \%$ of the total sample, a considerable space for improvement is recorded.

The need for improvement actions can be more obvious as in certain criteria such as this of pricing policy the level of satisfaction is very low. Nonetheless, the criteria with low performance are in the so called "status-quo" and are of the action diagram, which means they are not significantly important for industrial customers' satisfaction; thus, the natural gas providers should not invest very high resources in improving these criteria. Moreover, according to the MUSA method's results, the criterion located in the leverage opportunity area of the action diagram is this of products and services; thus, this is the most important criterion for industrial customer satisfaction and should be in the spotlight of natural gas providers.

These results could be used by energy providers' managers as a guidance for their strategy development. Measuring customer satisfaction as a useful insight on the performance of a company dealing with the needs of its customers can arise. The critical analysis of such results could significantly 
contribute to the disclosure of the actions that should be undertaken in order to increase customer satisfaction [3]. Such results are crucial for decisions concerning improvement actions and resources allocation as well.

We should note that the present research has some limitations. First, what should be taken into consideration for the results of the survey is that it has been carried out in the beginning of the natural gas market in Greece full liberalization period. This means that until the beginning of the survey, the choices in the market for alternative providers were relatively limited. This may also explain the fact that while satisfaction from criteria such as this concerning pricing policy is low, the level of demanding is low as well, in contrast to the results of other surveys [78]. This trend is most likely to change with the operation of a fully liberalized market. Especially in the case of natural gas, which is a strategic choice for the European Union and consequently for Greece, market growth margins and competition intensities will increase. Thus, the strategic importance of customer satisfaction will keep growing constantly [87].

Despite the fact that we see that the results do not differ between the different industrial sectors of the respondents, they should be tentatively accepted. This means that they cannot be automatically generalized [3] before a systematic replication is achieved [88]. Besides, the results of similar surveys show that there are differences in the satisfaction level of industrial customers belonging to different sectors and, as far as it is concerned, there is a need for different strategic choices [3,73].

Furthermore, this research is based on data which are not longitudinal offering a static view. In such cases as the examined one, it is important to use data concerning customer satisfaction over time in order to track over longer periods of time.

Last, the questionnaire used mainly included questions related to the measurement of industrial customers' satisfaction as the main objective was to calculate satisfaction indices. Factors related to customer satisfaction such the change rate of service providers, the purchase of added services, the willingness to pay or customers' loyalty are not examined. These factors are found to be strongly correlated with customer satisfaction in similar studies [15,73].

Based on the above analysis and the limitations noticed, there are several avenues for future research. First, more analytical research including the above mentioned factors related to customer satisfaction should be run. At the same time, the applied questionnaire could be updated with more criteria concerning industrial customer satisfaction and address different roles (e.g., deciders, buyers, and users) within the industrial customers.

Furthermore, a survey combining both individual consumers' and industrial customers' satisfaction would more effectively underline the strong points and the areas in need of improvement of the natural gas providers.

Finally, the installation of a permanent satisfaction barometer, which could be run annually, is an important extension as it could give the ability to track changes concerning both individual consumers' and industrial customers' satisfaction.

Author Contributions: D.D., M.S. and N.T. gathered the data and carried out the satisfaction measurement using the MUSA method. G.A. and S.G. gathered and implemented all the theoretical background of the paper. D.D., M.S. and N.T. carried out the connection between literature and the customer satisfaction analysis, as well as the finalization of the article.

Funding: This research received no external funding.

Conflicts of Interest: The authors declare no conflict of interest.

\section{References}

1. Ahmad, N. Quality Attribute and Customer Satisfaction: Using Kano's Model to Prioritize What Matters Most to Customers. J. Mark. Consum. Behav. Emerg. Mark. 2017, 1, 15-28.

2. Skordoulis, M.; Alasonas, P.; Pekka-Economou, V. E-government services quality and citizens' satisfaction: A multi-criteria satisfaction analysis of TAXISnet information system in Greece. Int. J. Prod. Qual. Manag. 2017, 22, 82-100. [CrossRef] 
3. Homburg, C.; Rudolph, B. Customer satisfaction in industrial markets: Dimensional and multiple role issues. J. Bus. Res. 2001, 52, 15-33. [CrossRef]

4. Pham, C.H. Customer satisfaction on service quality of consumer goods retailers: Evidence from Vietnam. Int. J. Civ. Eng. Technol. 2019, 10, 1159-1175.

5. Shin, D.H. Effect of the customer experience on satisfaction with smartphones: Assessing smart satisfaction index with partial least squares. Telecommun. Policy 2015, 39, 627-641. [CrossRef]

6. Churchill, G.A., Jr.; Surprenant, C. An investigation into the determinants of customer satisfaction. J. Mark. Res. 1982, 19, 491-504. [CrossRef]

7. Yashin, N.S.; Popova, L.F.; Bocharova, S.V.; Bagautdinova, N.G. Customer satisfaction assessment in management quality system of industrial enterprises. Int. Bus. Manag. 2016, 10, 5720-5726.

8. Festge, F.; Schwaiger, M. The Drivers of Customer Satisfaction with Industrial Goods: An International Study. Adv. Int. Mark. 2007, 18, 179-207.

9. Ismail, H.; Bakar, Z.; Salleh, A.H.M. Buyer satisfaction and loyalty - Evidence from the industrial goods market. J. Pengur. 2006, 25, 47-61.

10. Tong, L.; Hou, X.; Li, X. Empirical study on customer satisfaction influencing factors of industry application products based on experiential level theory. China Commun. 2016, 13, 260-268. [CrossRef]

11. Dincer, I. Environmental and sustainability aspects of hydrogen and fuel cell systems. Int. J. Energy Res. 2007, 31, 29-55. [CrossRef]

12. Papageorgiou, A.; Skordoulis, M.; Trichias, C.; Georgakellos, D.; Koniordos, M. Emissions trading scheme: Evidence from the European Union countries. In Communications in Computer and Information Science; Kravets, A., Shcherbakov, M., Kultsova, M., Shabalina, O., Eds.; Springer International Publishing: Cham, Switzerland, 2015; pp. 222-233.

13. Chalikias, M.S.; Kolovos, K.G. Citizens' views in Southern Greece part II. Contribution of forests to quality of life. J. Environ. Prot. Ecol. 2013, 2, 629-637.

14. Chalikias, M. Effect of natural recourses and socioeconomic features of tourists on the Greek tourism. J. Environ. Prot. Ecol. 2012, 13, 1215-1226.

15. Ntanos, S.; Kyriakopoulos, G.; Chalikias, M.; Arabatzis, G.; Skordoulis, M. Public perceptions and willingness to pay for renewable energy: A case study from Greece. Sustainability 2018, 10, 687. [CrossRef]

16. Ntanos, S.; Kyriakopoulos, G.; Skordoulis, M.; Chalikias, M.; Arabatzis, G. An Application of the New Environmental Paradigm (NEP) Scale in a Greek Context. Energies 2019, 12, 239. [CrossRef]

17. Skordoulis, M.; Chalikias, M.; Galatsidas, S.; Arabatzis, G. Competitive Advantage Establishment through Sustainable Environmental Management and Green Entrepreneurship: A Proposed Differential Equations Framework. In Springer Earth System Sciences; Theodoridis, A., Ragkos, A., Salampasis, M., Eds.; Springer International Publishing: Cham, Switzerland, 2019; pp. 205-219.

18. Di Pascoli, S.; Femia, A.; Luzzati, T. Natural gas, cars and the environment. A (relatively) 'clean' and cheap fuel looking for users. Ecol. Econ. 2001, 38, 179-189. [CrossRef]

19. Zerva, A.; Tsantopoulos, G.; Grigoroudis, E.; Arabatzis, G. Perceived citizens' satisfaction with climate change stakeholders using a multicriteria decision analysis approach. Environ. Sci. Policy 2018, 82, 60-70. [CrossRef]

20. Manolitzas, P.; Kostagiolas, P.; Grigoroudis, E.; Intas, G.; Stergiannis, P. Data on patient's satisfaction from an emergency department: Developing strategies with the Multicriteria Satisfaction Analysis. Data Brief 2018, 21, 956-961. [CrossRef]

21. Borishade, T.; Kehinde, O.; Iyiola, O.; Olokundun, M.; Ibidunni, A.; Dirisu, J.; Omotoyinbo, C. Dataset on customer experience and satisfaction in healthcare sector of Nigeria. Data Brief 2018, 20, 1850-1853. [CrossRef]

22. Drosos, D.; Tsotsolas, N.; Skordoulis, M.; Chalikias, M. Patient satisfaction analysis using a multi-criteria analysis method: The case of the NHS in Greece. Int. J. Prod. Qual. Manag. 2018, 25, 491-505. [CrossRef]

23. Fang, Y.H.; Chiu, C.M.; Wang, E.T. Understanding customers' satisfaction and repurchase intentions: An integration of IS success model, trust, and justice. Intern. Res. 2011, 21, 479-503. [CrossRef]

24. Kadlubek, M.; Grabara, J. Customers' expectations and experiences within chosen aspects of logistic customer service quality. Intern. J. Qual. Res. 2015, 9, 265-278.

25. Tsafarakis, S.; Kokotas, S.; Pantouvakis, A. A multiple criteria approach for airline passenger satisfaction measurement and service quality improvement. J. Air Transport. Manag. 2018, 68, 61-75. [CrossRef] 
26. Vijayabanu, C.; Renganathan, R.; Badrinath, V.; Vijay Anand, V.; Chandrasekar, S.; Parthasaarathy, A.K.; Ganapathi Narendra Subburam, U. Customer satisfaction in aviation industry. Int. J. Appl. Bus. Econ. Res. 2017, 15, 397-405.

27. Bouranta, N.; Siskos, Y.; Tsotsolas, N. Measuring police officer and citizen satisfaction: Comparative analysis. Policing 2015, 38, 705-721. [CrossRef]

28. Aouadni, I.; Rebaï, A.; Christodoulakis, N.; Siskos, Y. Job satisfaction measurement: The multi-criteria satisfaction analysis. Int. J. Appl. Decis. Sci. 2014, 7, 190-207. [CrossRef]

29. Chen, S.C. The customer satisfaction-loyalty relation in an interactive e-service setting: The mediators. J. Retail. Consum. Serv. 2012, 19, 202-210. [CrossRef]

30. Drosos, D.; Tsotsolas, N.; Manolitzas, P. The relationship between customer satisfaction and market share: The case of mobile sector in Greece. Int. J. Eng. Manag. 2011, 3, 87-105.

31. Ostrom, A.; Iacobucci, D. Consumer trade-offs and the evaluation of services. J. Mark. 1995, 59, 17-28. [CrossRef]

32. Woodside, A.G.; Frey, L.L.; Daly, R.T. Linking service quality, customer satisfaction and behavioral intention. J. Health Care Mark. 1989, 9, 5-17.

33. Yi, Y. A critical review of consumer satisfaction. In Review of Marketing; Zeithaml, V.A., Ed.; American Marketing Association: Chicago, IL, USA, 1990; pp. 68-123.

34. Aghamirian, B.; Dorri, B.; Aghamirian, B. Customer knowledge management application in gaining organization's competitive advantage in electronic commerce. J. Theor. Appl. Electron. Comm. Res. 2015, 10, 63-78. [CrossRef]

35. Kotler, P. Marketing Management: Analysis, Planning, Implementation, and Control; Prentice Hall: Englewood Cliffs, NJ, USA, 1991.

36. O'Sullivan, D.; McCallig, J. Customer satisfaction, earnings and firm value. Eur. J. Mark. 2012, 46, 827-843. [CrossRef]

37. Balmer, J.M.T.; Chen, W. Corporate heritage brands, augmented role identity and customer satisfaction. Eur. J. Marke. 2017, 51, 1510-1521. [CrossRef]

38. Luo, X.; Homburg, C.; Wieseke, J. Customer satisfaction, analyst stock recommendations, and firm value. J. Mark. Res. 2010, 47, 1041-1058. [CrossRef]

39. O'Connell, V.; O'Sullivan, D. The impact of customer satisfaction on CEO bonuses. J. Acad. Mark. Sci. 2011, 39, 828-845. [CrossRef]

40. Ryu, K.; Lee, H.R.; Kim, W.G. The influence of the quality of the physical environment, food, and service on restaurant image, customer perceived value, customer satisfaction, and behavioral intentions. Int. J. Contemp. Hosp. Manag. 2012, 24, 200-223. [CrossRef]

41. Anderson, E.W.; Mittal, V. Strengthening the satisfaction-profit chain. J. Serv. Res. 2000, 3, 107-120. [CrossRef]

42. Alegre, J.; Cladera, M. Analysing the effect of satisfaction and previous visits on tourist intentions to return. Eur. J. Mark. 2009, 43, 670-685. [CrossRef]

43. Steven, A.B.; Dong, Y.; Dresner, M. Linkages between customer service, customer satisfaction and performance in the airline industry: Investigation of non-linearities and moderating effects. Transp. Res. Part E 2010, 48, 743-754. [CrossRef]

44. Banker, R.D.; Mashruwala, R. The moderating role of competition in the relationship between nonfinancial measures and future financial performance. Contemp. Acc. Res. 2007, 24, 763-793. [CrossRef]

45. Jani, D.; Han, H. Investigating the key factors affecting behavioral intentions: Evidence from a full-service restaurant setting. Int. J. Contemp. Hosp. Manag. 2011, 23, 1000-1018. [CrossRef]

46. Ranaweera, C.; Prabhu, J. On the relative importance of customer satisfaction and trust as determinants of customer retention and positive word of mouth. J. Target. Meas. Anal. Mark. 2003, 12, 82-90. [CrossRef]

47. Pantelidis, I.S. Electronic meal experience: A content analysis of online restaurant comments. Cornell Hosp. Q. 2010, 51, 483-491. [CrossRef]

48. Tsai, H.T.; Huang, H.C. Determinants of e-repurchase intentions: An integrative model of quadruple retention drivers. Inf. Manag. 2007, 44, 231-239. [CrossRef]

49. Williams, P.J.; Naumann, E. Customer satisfaction and business performance: A firm-level analysis. J. Serv. Mark. 2011, 25, 20-32. [CrossRef]

50. Yeung, M.C.H.; Ennew, C.T. Measuring the impact of customer satisfaction on profitability: A sectoral analysis. J. Target. Meas. Anal. Mark. 2001, 10, 106-116. [CrossRef] 
51. Dong, K.Y.; Jeong, A.P. Perceived service quality: Analyzing relationships among employees, customers, and financial performance. Int. J. Qual. Reliabil. Manag. 2007, 24, 908-926.

52. Chi, C.G.; Gursoy, D. Employee satisfaction, customer satisfaction, and financial performance: An empirical examination. Int. J. Hosp. Manag. 2009, 28, 245-322. [CrossRef]

53. Gruca, T.S.; Rego, L.L. Customer satisfaction, cash flow, and shareholder value. J. Mark. 2005, 69, 115-130. [CrossRef]

54. Winkler, G.; Schwaiger, M.S. Is customer satisfaction driving revenue-A longitudinal analysis with evidence from the banking industry? J. Bus. Econ. Res. 2004, 2, 11-22. [CrossRef]

55. Grewal, R.; Chandrashekaran, M.; Citrin, A.V. Customer satisfaction heterogeneity and shareholder value. J. Mark. Res. 2010, 47, 612-626. [CrossRef]

56. Merrin, R.P.; Hoffmann, A.O.I.; Pennings, J.M.E. Customer satisfaction as a buffer against sentimental stock-price corrections. Mark. Lett. 2013, 24, 13-27. [CrossRef]

57. Tuli, K.; Bharadwaj, S. Customer Satisfaction and Stock Returns Risk. J. Mark. 2009, 73, 184-197. [CrossRef]

58. Gounaris, S.P.; Avlonitis, J.G.; Kouremenos, A.; Papavassiliou, N.; Papathastopoulou, P. Market share and customer satisfaction: What is the missing link? J. Euromark. 2002, 10, 61-82. [CrossRef]

59. Rego, L.L.; Morgan, N.A.; Fornell, C. Reexamining the Market Share-Customer Satisfaction Relationship. J. Mark. 2013, 77, 1-20. [CrossRef]

60. Rossomme, J. Customer satisfaction measurement in a business-to-business context: A conceptual framework. J. Bus. Ind. Mark. 2003, 18, 179-195. [CrossRef]

61. Raj Kumar, R.J.; Krishnaven, V. Satisfaction of industrial customers with regard to usage of zippers. J. Adv. Res. Dyn. Control Syst. 2017, 9, 144-148.

62. Gerson, R.F. Measuring Customer Satisfaction: A Guide to Managing Quality Service; Crisp Publications: Menlo Park, CA, USA, 1993.

63. Siskos, Y.; Grigoroudis, E.; Zopounidis, C.; Saurais, O. Measuring customer satisfaction using a collective preference disaggregation model. J. Glob. Optim. 1998, 12, 175-195. [CrossRef]

64. Chalikias, M.; Drosos, D.; Skordoulis, M.; Tsotsolas, N. Determinants of customer satisfaction in healthcare industry: The case of the Hellenic Red Cross. Int. J. Electron. Mark. Retail. 2016, 7, 311-321. [CrossRef]

65. Medjoudj, R.; Aissani, D.; Haim, K.D. Power customer satisfaction and profitability analysis using multi-criteria decision making methods. Int. J. Electr. Power Energy Syst. 2013, 45, 331-339. [CrossRef]

66. Walsh, G.; Dinnie, K.; Wiedmann, K.P. How do corporate reputation and customer satisfaction impact customer defection? A study of Private Energy Customers in Germany. J. Serv. Mark. 2006, 20, 412-420. [CrossRef]

67. Elliot, J.; Serna, C. Managing customer satisfaction involves more than improving reliability. Electr. J. 2005, 18, 84-89. [CrossRef]

68. Mutua, J.; Ngui, D.; Osiolo, H.; Aligula, E.; Gachan, J. Consumers satisfaction in the energy sector in Kenya. Energy Policy 2012, 48, 702-710. [CrossRef]

69. J.D. Power. Gas Utility Business Customer Satisfaction Study; J.D. Power: Troy, MI, USA, 2016.

70. J.D. Power. Gas Utility Residential Customer Satisfaction Study; J.D. Power: Troy, MI, USA, 2016.

71. American Customer Satisfaction Index. ACSI Utilities, Shipping, and Health Care Report; ACSI: Ann Arbor, MI, USA, 2017.

72. Liu, B.; Zhang, T.; Zhou, W.; Chan, X. Research of electricity customer satisfaction evaluation on service blueprint. Wirel. Commun. Netw. Mob. Comput. 2007, 3168-3171.

73. Chodzaza, G.E.; Gombachika, H.S. Service quality, customer satisfaction and loyalty among industrial customers of a public electricity utility in Malawi. Int. J. Energy Sect. Manag. 2013, 7, 269-282. [CrossRef]

74. Jannadi, O.A.; Al-Saggaf, H. Measurement of quality in Saudi Arabian service industry. Int. J. Qual. Reliabil. Manag. 2000, 17, 949-966. [CrossRef]

75. Medjoudj, R.; Laifa, A.; Aissani, D. Decision making on power customer satisfaction and enterprise profitability analysis using the Analytic Hierarchy Process. Int. J. Prod. Res. 2012, 50, 4793-4805. [CrossRef]

76. Ibáñez, V.A.; Hartmann, P.; Calvo, P.Z. Antecedents of customer loyalty in residential energy markets: Service quality, satisfaction, trust and switching costs. Serv. Ind. J. 2006, 26, 633-650. [CrossRef]

77. Hartmann, P.; Ibáñez, V.A. Managing customer loyalty in liberalized residential energy markets: The impact of energy branding. Energy Policy 2007, 35, 2661-2672. [CrossRef] 
78. García-Acebrón, C.; Vázquez-Casielles, R.; Iglesias, V. The effect of perceived value and switching barriers on customer price tolerance in industrial energy markets. J. Bus.-to-Bus. Mark. 2010, 17, 317-335. [CrossRef]

79. Fuels Europe. Statistical Report 2018; Fuels Europe: Brussels, Belgium, 2018.

80. Eurostat. Natural Gas Supply Statistics. 2019. Available online: https:/ / ec.europa.eu/eurostat/statisticsexplained/ index.php?title=Natural_gas_consumption_statistics\&oldid=88292 (accessed on 3 February 2019).

81. Public Company of Gas Supply of Greece (DEPA). Commercial Operation. 2015. (In Greek)Available online: http:/ / www.depa.gr/content/article/002003007/112.html (accessed on 20 December 2018).

82. Ipsilandis, P.G.; Samaras, G.; Mplanas, N. A multicriteria satisfaction analysis approach in the assessment of operational programmes. Int. J. Proj. Manag. 2008, 26, 601-611. [CrossRef]

83. Grigoroudis, E.; Siskos, Y. Preference disaggregation for measuring and analysing customer satisfaction: The MUSA method. Eur. J. Oper. Res. 2002, 143, 148-170. [CrossRef]

84. Ipsos; London Economics; Deloitte. Second Consumer Market Study on the Functioning of the Retail Electricity Markets for Consumers in the EU. Country Fiches; European Commission: Brussels, Belgium, 2016.

85. Agnihotri, R.; Gabler, C.B.; Itani, O.S.; Jaramillo, F.; Krush, M.T. Salesperson ambidexterity and customer satisfaction: Examining the role of customer demandingness, adaptive selling, and role conflict. J. Pers. Sell. Sales Manag. 2017, 37, 27-41. [CrossRef]

86. Kumar, V.; Batista, L.; Maull, R. The impact of operations performance on customer loyalty. Serv. Sci. 2011, 3, 158-171. [CrossRef]

87. Drosos, D.; Tsotsolas, N.; Chalikias, M.; Skordoulis, M.; Koniordos, M. Evaluating customer satisfaction: The case of the mobile telephony industry in Greece. In Communications in Computer and Information Science; Kravets, A., Shcherbakov, M., Kultsova, M., Eds.; Springer International Publishing: Cham, Switzerland, 2015; pp. 249-267.

88. Jacoby, J. Consumer research: A state-of-the-art review. J. Mark. 1978, 42, 87-96. [CrossRef]

(C) 2019 by the authors. Licensee MDPI, Basel, Switzerland. This article is an open access article distributed under the terms and conditions of the Creative Commons Attribution (CC BY) license (http:/ / creativecommons.org/licenses/by/4.0/). 